\title{
Análise do Perfil de Resistência Aos Beta-Lactâmicos em Escherichia coli Isolada de Carcaças de Frango de Granja e "Caipira"
}

\author{
Vanessa Lumi Koga (I), Gabriela Regina Rodrigues (I), Paula \\ Signolfi Cyoia (I), Gerson Nakazato (I), Eliana Carolina Vespero (I), \\ Benito Guimarães de Brito (II), Kelly Cristina Tagliari de Brito (II), \\ Renata Katsuko Takayama Kobayashi (I) \\ (I) UEL - Universidade Estadual de Londrina (Rodovia Celso Garcia Cid Pr 445 Km 380 /Cx. \\ Postal 10.011 CEP 86.057-970 ), (II) IPVDF - Instituto de Pesquisas Veterinárias Desidério \\ Finamor (Estrada Municipal do Conde, 6000. Eldorado do Sul / RS)
}

\section{Resumo}

O aumento de bactérias resistentes aos antimicrobianos tem sido umas das principais preocupações na saúde humana, e vem se tornando também um problema para a medicina veterinária. Os antimicrobianos são usados na produção animal para prevenir ou tratar infecções bacterianas. No entanto, muitas vezes, os antimicrobianos são adicionados à alimentação de animais, como na avicultura, como promotores de crescimento. A presença de resistência aos antimicrobianos em alimentos de origem animal tem sido preocupante, pois as bactérias isoladas podem ser reservatórios de genes de resistência e virulência, tendo um papel importante na disseminação destas resistências às bactérias patogênicas e comensais humanas. Neste trabalho, 121 amostras de Escherichia coli foram isoladas de um total de 35 carcaças de frango, comercializadas em supermercados (frangos de granja), e 35 amostras de E. coli de um total de 15 carcaças de frango, originadas da agricultura familiar (frangos caipira). Foi realizado o antibiograma para os seguintes antimicrobianos: ampicilina, amoxicilina-ácido clavulânico, cefazolin, cefoxitina, ceftazidima e cefotaxima. As amostras resistentes às cefalosporinas de $3^{a}$ geração, foram utilizadas para o teste fenotípico de detecção de betalactamases de espectro estendido (ESBL), por meio do

\footnotetext{
Referência:

Vanessa Lumi Koga, Gabriela Regina Rodrigues, Paula Signolfi Cyoia, Gerson Nakazato, Eliana Carolina Vespero, Benito Guimarães de Brito, Kelly Cristina Tagliari de Brito, Renata Katsuko Takayama Kobayashi. Análise do Perfil de Resistência Aos Beta-Lactâmicos em Escherichia coli Isolada de Carcaças de Frango de Granja e "Caipira". In: Anais do $12^{\circ}$ Congresso Latinoamericano de Microbiologia e Higiene de Alimentos - MICROAL 2014 [= Blucher Food Science Proceedings, num.1, vol.1]. São Paulo: Editora Blucher, 2014. DOI 10.5151/foodsci-microal-317
} 
teste de aproximação de discos e pelo teste do disco combinado. Nossos resultados mostraram que a resistência aos beta-lactâmicos em amostras isoladas de frango caipira é praticamente ausente, apresentando apenas $20 \%$ das amostras resistentes a ampicilina e 2,86\% para cefazolin. Já para as amostras isoladas de frango de granja, há uma alta prevalência de resistência para ampicilina (66,94\%), cefazolin $(48,76 \%)$ e cefotaxima $(31,4 \%)$, sendo $32,23 \%$ dessas amostras positivas para o teste fenotípica de detecção de ESBL, diferentemente das amostras isoladas de frango caipira, que não apresentaram essa enzima. Visto que muitos estudos têm discutido a respeito do risco de transferência genética entre isolados aviários e humanos, a presença de ESBL em amostras isoladas de carcaças de frango se mostra um perigo para a saúde humana, sendo esta enzima uma das grandes causas de falha terapêutica em tratamentos de infecções bacterianas.

Palavras-Chave: Escherichia coli, resistência, ESBL Agência de Fomento: CNPq - ANVISA 